\title{
THE HISTORY OF VILNIUS OLD JEWISH CEMETERY AT ŠNIPIŠKĖS IN THE PERIOD OF THE GRAND DUCHY OF LITHUANIA
}

\author{
Elmantas Meilus
}

ABSTRACT The recent international outcry concerning an old Jewish cemetery once again being destroyed in a former suburb of Vilnius, namely Šnipiškes (nowadays in the very centre of the city), forces us to revise the history of its origin and development in the period of the Grand Duchy of Lithuania. Summarizing the history of the cemetery, one plausible conclusion is that the cemetery was established on state-owned land in the jurisdiction of the Castle possibly in the late fifteenth century and the first reliable historical data goes back to the late sixteenth century in relation to tax exemptions. A comparison of historical, cartographic and archaeological data permits to make a valid assumption that the oldest burials from the second half of the sixteenth century were located in the south-western and central section of the cemetery based on the layout of 1808 (in the area between the Sports Hall and swimming pool built in the Soviet period). The cemetery developed gradually by acquiring separate state land plots belonging to the Castle Authority (Horodnictwo) and Forestry Authority (Derewnictwo) which were rented by different persons and by taking over payment of the taxes and fees they used to pay. The general situation of the cemetery at that period was marked in the plan from the Fürstenhof collection, drafted in approximately 1730. The Jewish cemetery was combined into one mas out of separate plots around 1790 in listing the urban possessions (land plots). Such situation was reflected in the layout of 1808 (possession no. 1116).

The recent international outcry concerning the destruction of this old Jewish cemetery in the former suburb Šnipiškès of Vilnius forces us to revise the history of its origin and development. ${ }^{1}$ One or other aspect of this issue has been discussed to a varying degree in a number of publications (those known and available to the author will be referred to in the text), yet a detailed and exhaustive study of the cemetery in question was published by Israel Klausner only in

\footnotetext{
${ }^{1}$ A study on the development of the cemetery in the nineteenth-twentieth centuries has been prepared by Dr Vytautas Jogèla.
} 
$1935 .^{2}$ Referring to the sources available in Vilnius at that time, the said author prepared a substantial study on the development of the cemetery, burials and the most significant people buried there. For the present article the archival records used by Klausner and some new sources located in Vilnius (e.g. the Lithuanian Metrica which at that time was unavailable to Klausner) have been reviewed and every source has yielded new material which will be provided in footnotes in great detail in the way it is written in the source along with the sources used by the said author and his study itself.

The exact date when the old Vilnius Jewish cemetery was established is not known. A number of encyclopaedias and sources on the subject refer to 1487 (in some instances to 1477 ), ${ }^{3}$ but this date has not been substantiated yet by any sources, although some authors refer to this date and even believe that it proves existence of the Jewish community in the town. ${ }^{4}$ Sometimes it is noted that

${ }^{2}$ I. Klausner, Dzieje starego cmentarza żydowskiego $w$ Wilnie (Vilnius, 1935) (in Hebrew, a manuscript translation into Lithuanian of a part of the book made by L. Lempertiene and a Polish abstract of the book have been used), p. I; W. M., review of Klausner, Dzieje starego cmentarza żydowskiego $w$ Wilnie, Ateneum Wileńskie, Rocz. 11, 1936, pp. 630-631; thanks to the unpublished paper by Prof. David Fishman who kindly allowed the author to read his work (Historical Overview of the Jewish Cemetery in Shnipishok), I learned that the study by Klausner was reprinted in Jerusalem in 1972.

${ }^{3}$ Klausner, Dzieje, pp. 3-5; Jüdisches Lexikon, Ein enzyklopädisches Handbuch des jüdischen Wissens in vier Bänden, begründet von Dr. G. Herlitz und Dr. B. Kirschner, Band IV/2, p. 1439; Lite, 1 Bd., eds. M. Sudorski, U. Karenellnbogen (New York, 1951), p. 1135; Evreiskaia entsiklopedia, vol. 5 (St Peterburg, 1909), pp. 573, 590-591; Jerusalem of Lithuania, Illustrated and documented. Collected and arranged by Leyzer Ran, Vol. I (New York, 1974), p. 100; E. Małachowicz, Wilno. Dzieje, architektura, cmentarze (Wrocław, 1996), pp. 184, 459; 'Vilnius (in Yiddish Vilne) made the Lithuanian Jews particularly famous in the world. Jews came to live here rather late in comparison with other towns, only in the second half of the sixteenth century. Admittedly, one document is often referred to which supposedly says that the Jewish cemetery was located there already in 1487. However, the document has not survived and its information cannot be proved, whereas the existing knowledge of the laws and customs of that time lead us to believe that such information is not correct. The Jews living in Vilnius were first mentioned in a document dated 1567. Yet at that time they had no right to buy houses, only to rent them; the Jews gained the right to buy buildings in Vilnius only in 1593', see: 'Žydai Lietuvoje', (in: http://litvakai.mch. mii.lt// [accessed on 20 Apr. 2009].

${ }^{4}$ D. Blažyte, 'Vilniaus magistratas ir žydų bendruomenė XVIII amžiuje', Vilniaus Gaonas ir žydu kultūros keliai, Tarptautinès mokslinès konferencijos medžiaga (Vilnius, 1999), pp. 293-299, reprinted in Vilniaus miesto istorijos skaitiniai, comp. by E. Manelis, R. Samavičius (Vilnius, 2001), pp. 134-137. 
the first evidence of a community of Jews in Vilnius comes from 1568 when it was ordered to pay a poll tax ${ }^{5}$. However, Sergei Bershadskii critically reviewed earlier studies of this matter and on the basis of sources he expressed well-reasoned doubts about existence of a Jewish community in Vilnius before the end of the sixteenth century. ${ }^{6}$ Scholarship on this subject indicates that the first unquestionable documents referring to that cemetery date to the late sixteenth century, when Sigismund Vasa granted the Jews a charter which, in addition to the right of permanent residence in Vilnius, allowed Jews to have their own cemetery. ${ }^{7}$ Yet Bershadskii notes that there seems to have been two charters granted by Sigismund Vasa. The first charter dated 1 June 1593 legalized their residence in the city, whereas the second one, which allowed Jews to have a synagogue and cemetery in Vilnius, has not survived. The date of the second charter is not clear and the text is known to the author only from the charter of 19 February 1633 issued by Władislaw IV confirming the charter of 1593 and according to Bershadskii masterfully incorporating the texts of both documents. ${ }^{8}$ It seems that neither Bershadskii, nor Klausner was aware of a charter, dated 29 March 1629, granted by Sigismund Vasa. ${ }^{9}$ It stipulates that upon

${ }^{5}$ A. Budreckis, 'Vilniaus žydų istorijos apžvalga', Voruta, 1994/12, no. 45(183), reprinted in Vilniaus miesto istorijos skaitiniai, pp. 143-147; Kratkaia evreiskaia entsiklopedia, ed. N. Oren (Nadel), vol. 1 (Moscow, 1996), p. 667.

${ }^{6}$ S. Bershadskii, 'Ocherk istorii vilenskoi evreiskoi obshchiny (1593-1793)', Voskhod, no. 7, 1881; idem, 'Istoriia vilenskoi evreiskoi obshchiny (1593-1649)', Voskhod, nos. 10, 11, 1886.

${ }^{7}$ Bershadskii, 'Ocherk', p. 94; idem, 'Istoriia', no. 3, 1882, pp. 82-83; Dzieje..., p. 5, I (Resume).

${ }^{8}$ Bershadskii, 'Istoriia', no. 3, 1887, p. 82.

${ }^{9}$ LVIA, Lithuanian Metrica (microfilm), 99, fos. 308v-309. Document dated 29 March 1629: Confirmatia na okopiscze łazniq jatki zydom y insze punkta,

Zygmunt III

Oznaymuiemy tym listem naszym ... Iz poktadany byt przed nami Przywiley nasz zydom Wilenskim od nas dany $w$ ktorym my mieszkania abo domow u szlachty nabywac y dostawac onego spokoynie bez wszelakiego zatrudnienia petnienia powinnosci y cięzarow zazywac, obrzędy wedtug zakonow ich odprawowac, handle $y$ kupie rozmaite, iako y inszi poddani naszi wedlug wolnosci y przywileiow od Naiasnieyszych niegdy Antecessorow naszych nadanych y przez nas confirmowanych, po wszytkim WXL Zydom tamecznym wiesc y prowadzic. Jurisdictiey tylko samey Zamkowey podlegaiqc pozwolilismy. Supplicowali tedy nam Samuel y Łazar Moyzeszowiczowe zydzi Wilenscy swym y wszytkiego zboru Wilenskiego imieniem przez PP Rady y Urzędniki nasze na ten czas przy boku naszym będace, abysmy 
approval of the 1593 charter, the following freedoms are granted at the request of Vilnius Jews: they are allowed [to keep] a fenced land plot or a small cemetery to bury their dead free of any duties (as it should have been until now) for ever, to have butcher's shops in Vilnius near their house of worship, and they are allowed to continue freely using the bath-house they have and their buildings as well as reconstruct their shrine. Thus this charter legalized the existing cemetery in 1629 and though its location is not indicated, it is obviously the cemetery at Šnipiškès. Nonetheless, the end of the fifteenth century and the first half of the sixteenth century may not be dismissed completely as the date for Jewish burials beginning in that location, though Jews still did not have permission to reside in

im takowe prawa ninieyszym listem naszym stwierdziwszy, niektore pewne wolnosci nadali, jakoz y ninieyszym listem naszym, laskawie do przyczyny PP Rad y Urzędnikow naszych przychilaiqc się onym nadaiemy. Tak $i z$ wolno im będzie ogrod abo kopiszcze dla chowania ciat zmarlych, bez zadnych podatkow (iako iuz trzymali y dotad trzymaia) wiecznym prawem. Takze tez y jatki mięsne przy boznicy stoiqce trzymac, zachowuiemy ich przytem przy wolnem uzywaniu zbudowaney tazni y paleniu oney kiedy im potrzeba będzie, do ktorey iednak uzywania Chrzescianie pod utrate teyze tazni, ani do postug przypuszczani byc niemaiq y przy wolnem sqdzieniu // zeby się miedzy sobq wedlug porzqdku y zwyczaiu swego $w$ sprawach priwatnych sqdzic y karac mogli. Tak tez przy prawach na domy y kamienice w miescie naszym Wilenskim nabytych iako przy domach od wielmoznego Leona Sapiehi woiewody Wilenskiego hetmana naszego WXLitt y od urodzonego Thomasza Bildziukiewicza sekretarza naszego woyta Wilenskiego na Zydowskiey ulicy lezacych, takze przy kamienicy od wielmoznego Janusza Kiszki woiewody Połockiego na Niemieckiey ulicy stoiqcey y przy domie od wielmoznego niegdy Janusza Radziwiła casztelana Wilenskiego nabytym, na boznice obroconym, ktora poprawiac tylko y restaurowac, a nie inna z gruntu budowac pozwalamy. Wolno im będzie pomienionych domow y kamienice spokoynie uzywac poprawiac zamieniac przedac, dac, darowac y iako swa wtasnosciq szafowac. Co do wiadomosci wszem wobec y kazdemu, a mianowicie urzędowi Grodzkiemu y Mieysckiemu Wilenskiemu, teraznieyszemu y napotem będacemu donoszac, chcemy miec y rozkazuiemy, aby przy zwysz mianowanych wolnosciach y prawach zydzi Wilenscy od nas im ninieyszym listem nadanych y potwierdzonych, $w$ cale y nienaruszenie chowani byli, wiecznemi czasy dla łaski naszey. I na tosmy dali ten list Przywiley nasz z podpisem ręki naszey y s pieczęciq WXL. Dan w Warszawie... Panowania krolestw naszych Polskiego XXXXII, a Szwedzkiego XXXVI roku. Sigismundus Rex. Marcyan Tryzna pisarz WXL; this charter was confirmed later by King Jan Kazimierz, see: LVIA, SA, 4811, pp. 78-79. This book of the Lithuanian Metrica recorded Jewish charters on 26 and 27 of March, which were confirmed and supplemented and the charter of 1 June 1593 was entered (LVIA, LM, Book 99, fos. 305-307), also see Z. Kiaupa, 'Wilno w czasach pierwszych Wazów', Litwa w epoce Wazów. Prace ofiarowane Henrykowi Wisnerowi w siedemdziesiata rocznice urodzin, eds. W. Kriegseisen and A. Rachuba (Warsaw, 2006), pp. 94-95. 
Vilnius. Yet, as Bershadskii notes, there are some data suggesting that a few of them already lived there for a longer or shorter period. Finally, they may have settled gradually on the fringe of the town, i.e. across the river at Šnipiškès, in the land belonging to the castle which was not subordinate to the town and a small cemetery might have appeared nearby.

The hypothesis that a cemetery may have been established in the location in question is further supported by an assumption that the first (wooden?) bridge (or a crossing) across the River Neris was built approximately in the place of the current King Mindaugas Bridge (near or in front of the Castle) ${ }^{10}$ and a road led from there (the would-be streets of Przeprawa, Derewnicka, now Rinktinès, and in around 1730 the street marked in the plan from G.M. Fürstenhof's collection across the Neris in front of the Castle) across the Fishermen's Suburb towards Molètai. To some extent it explains why the cemetery was established in such a rather strange location (in front of the Castle). ${ }^{11}$ Permission was obtained to bury Jews in the land plots ${ }^{12}$ assigned in lands overseen by the Castle warden (horodniczego) and the forester (derewniczego ${ }^{13}$ ) right across the Neris, behind the fishermen's lodges with land plots on the bank of the river. Since it seems that those land plots remained in the jurisdiction of the Castle, Jewish burials could have remained there even after the expulsion of Jews from the GDL in 1495 and after the prohibition on Jews' living in Vilnius in $1527,{ }^{14}$ as well as after

${ }^{10}$ Cf. M. Balinskis, Vilniaus miesto istorija (Vilnius, 2007), pp. 267-268; J. I. Kraszewski, Wilno od poczqtków jego do roku 1750, vol. 3 (Vilnius, 1841), p. 340; Wizerunki i roztrzasania naukowe. Poczet nowy drugi, vol. 22, pp. 54-55, 79; V. Drèma, Dingęs Vilnius (Vilnius, 1991), p. 376.

${ }^{11}$ It should be noted that the location in front of the Castle is rather unusual, see Klausner, Dzieje, p. 6.

${ }^{12}$ Idem, p. 6 and I; on the fact that Fishermen's the Suburb was on the land of the grand duke see M. Łowmiańska, Wilno przed najazdem moskiewskim 1655 roku (Vilnius, 1929), pp. 19-20 (also the second edition of this book: Dwa doktoraty $z$ uniwersitetu Stefana Batorego w Wilnie (Poznań, 2005), p. 168); more on land plots located nearby in other dependent lands see Drema, Vilniaus namai archyvu fonduose, XII knyga (Vilnius, 2006), pp. 16-21.

${ }^{13}$ Derewniczy, drewniczy... - forester, see K. Avižonis, Rinktiniai raštai, vol. II (Rome, 1978), p. 352; also see LVIA, LM, Book 123, 1. 140v-141, Conseruatia sławetnemu Urbanowi Kleynowi na worotnictwo zamku Wilen'z pensia zwyczayna $z$ dołozeniem powinnosci pilnowania drzewa Zamkowego z drzewnictwa Wilen' przychodzoncego. 23 Nov. 1649.

${ }^{14}$ More on the exile of 1495 and the prohibition of 1527 see Bershadskii, 'Ocherk', pp. 113-114; idem, 'Istoriia, 1886, no. 10, pp. 129, 131-132, 1887, no. 4, p. 67; Klausner, Dzieje, pp. 4-5. 
their permanent settlement in the town. Consequently, for over 100 years the few Jews who lived there for a longer or shorter period could bury their dead in those land plots with certain intervals, and since 1593 Jews had resided there permanently. In 1629 both the synagogue and the cemetery were legalised. ${ }^{15}$ This assumption is even more likely because so far no documents have been found which could clarify why the cemetery appeared in that particular location. In the first half of the sixteenth century when a permanent (stone) bridge was built at approximately the place of the current Green Bridge, Jews had always to make a considerable detour in order to reach the old cemetery because the Ulrich Hosius' charter regarding the construction of the bridge, disallowed other crossings in the territory of the city (and around). ${ }^{16}$ Therefore, if a new location was to be chosen in late fifteenth century, most likely it would be selected somewhere across the constructed stone bridge or close to what is now Kalvariju Street and not so far from the bridge, in front of the castle. Later additional land plots were bought from various sides (to be discussed below) and in that way the cemetery expanded and reached the river.

To pinpoint the oldest part of the cemetery is rather complicated. The layout provided in the book by Klausner and his description as well as dating of graves preserved until 1935 show that the oldest burials (from the first half of the seventeenth century) are approximately under the southern part of the Sports Hall constructed in the territory of the cemetery during the Soviet period (in the direction of the river). The fact that this territory (between the Sports Hall and the former swimming pool) may contain the oldest section of the cemetery is also witnessed by two undisturbed graves of two children buried according to Jewish tradition dating back to the second half of the sixteenth century as well as 10 disturbed graves of children found in the seventeenth-century cultural layer almost $110 \mathrm{~m}$ to the east from the first two found by archaeologist Robertas Žukovskis

\footnotetext{
15 The relevant literature (see: M. i K. Piechotkowie, 'Dzielnica żydowska i Wielka Synagoga w Wilnie', Lithuania, 2(3), 1991, p. 71; A. Jankevičienė, Vilniaus Didžioji Sinagoga (Vilnius, 1996), p. 4) sometimes indicates that the first synagogue in Vilnius was built in 1573 but this date, though very likely, so far has not been supported by sources (more on the issue see: Bershadskii, 'Ocherk', pp. 94, 118; idem, 'Istoriia', 1886, no. 11).

${ }^{16}$ For greater detail see Zbiór praw y przywilejów miastu stołecznemu WXL Wilnowi nadanych..., ed. P. Dubiński (Vilnius, 1788), pp. 48-53; for a Lithuanian translation of the privilege see Balinskis, Vilniaus miesto istorija, pp. 386-392.
} 
in 1996. ${ }^{17}$ All those and disturbed burials of children discovered in other trenches are on the fringe of the cemetery according to the outline of the cemetery marked in the layout of 1808 which is characteristic of Jewish burial tradition where children are buried on the edge of a cemetery. ${ }^{18}$

\section{During the unrest of 1634-1635 in Vilnius, the Jewish cemetery} in question was ravaged, 13 wooden and stone tombstones were smashed, Jews who came to a funeral were beaten. ${ }^{19}$ The confirm-

${ }^{17}$ Library of the Lithuanian Institute of History, Archaeology Dept, no. 2642: Žvalgomuju archeologiniu tyrimu Vilniuje, Rinktinès-Žveju g. ataskaita. [report] Part I. by R. Žukovskis, p. 3, Introduction: 'In October 1996 R. Žukovskis, an archaeologist of the Heritage Restoration Institute, conducted a test archaeological investigation in Vilnius, in the territory between Rinktinès and Žvejų Streets, to the south-east, south and west of the Sports Hall. ...All the trenches, based on the old maps of Vilnius, were excavated in the territory of the Jewish cemetery mentioned in the sixteenth century ... or nearby. The aim of the research was to establish the boundaries of the southern and western sections of the cemetery, the degree of its preservation,... 11 trenches were excavated. An area of 120 square metres was investigated. ..., p. 5 Data of the archaeological research: ... 'Trench 1. '... Nearly $2.10-2.15 \mathrm{~m}$ deep... 10 graves uncovered... They were buried with heads lying northwards, traces of decomposed coffins have been observed ... Fine ceramic pot shards were found in eye-sockets used to shut down eyelids. Based on the said ceramic shards and iron padlocks found above the graves, the burials can date to the seventeenth century ...possibly they are one-time graves of children who died of some epidemic. ...the remains were buried again.' Pp. 6-7, Trench 4: '...household ceramic pot shards found permit us to date this layer to the sixteenth century. Excavating this layer two undisturbed burials were found in the centre of the trench, almost $2.4 \mathrm{~m}$ deep. The dead were laid in the direction of south-east. The position of arms: in grave No. 1 - at the sides, in grave No. 2 - the right arm bent. In grave No. 1 between the legs of the dead in the area of knees a pot with a handle dating to the sixteenth century was placed bottom upwards as shroud ... Grave No. 2 was without shroud. ...Both burials were of children... their eye sockets were not covered with ceramic shards...'

${ }^{18}$ Comparison of archaeological and cartographic data was conducted by Dr Gediminas Vaitkevičius (see Lietuvos istorijos institutas, Žydu kapinés Šnipiškèse: ribu lokalizacija, Vilnius, 2007, typescript); Prof. Boris Khaimovich of Jerusalem University was consulted about Jew burials; on archaeological excavations in 2002-2003 on the western edge of the cemetery and a number of children's bones found from disturbed graves see http:/www.lietuvospilys.lt/data/zydai.htm; last accessed on 7 Sept. 2007.

${ }^{19}$ Akty izdavaemye Vilenskoiu Komissieiu dlia razbora drevnikh aktov (henceforth - AVAK), vol. XXVIII (Vilnius, 1901), pp. 136-137, no. 114, 4 Apr. 1634 testimony of wozny (a court official) regarding beatings and robbery of several dozens Jews which occurred (p. 137) na mogilniku ich żydowskim, wogrodzie za murowanym mostem, za Wilia, przy chowaniu żyda umarlego, od wielu rożnych kramnikó, rzemiesników...; pp. 137-139, no. 115, 8 Apr. 1634 a testimony of 
ation charter of King Michał Wiśniowiecki of 15 November 1669 attested a rescript of Władysław IV dated 25 May 1642, that Jews carrying their dead should be allowed to cross the bridge free of charge because they pay an annual tax for the bridge repairs. ${ }^{20}$ Such charters aroused dissatisfaction on the part of Holy Trinity Church and its alms-house because considerable income was lost. Therefore, after four years they managed to persuade the ruler and obtained a charter, allowing them to charge a toll on Jewish funeral

beadle regarding a meeting of Jews' representatives with Vilnius authorities in the town hall. He describes that on 3 April the Jews quarrelled with the town authorities concerning a land plot in the town and on the same day they were beaten in the cemetery; p. 147, no. 120, 7 March 1635. The complaint of Vilnius Jews against the magistrate mentions the last year fight in the cemetery and the fact that among others they were also beaten by local people there; pp. 150-151, no. 122, 8 March 1635. The complaint of Vilnius Jews regarding ravaging of their cemetery. ...naszedzsy tumultem wielkim mocno gwattem człowieka o kilka seth z różnymi broniami, do boiu należqcemi, na ogrod ych żałobliwych żydow, na przedmiesciu Wilenskim za Wiliq będqcym, gdzie ciała umarlych żydow chowaia, wpadszy do tego ogrodu, trzynascie grobow drzewianych y murowanych na mogiłach na szczqt porozbiiali y porozrzucali, deszek także trzynascie nad grobami stoiqce, ponapisowane pismem żydowskim, porozsiekali y wniwecz obrocili, y tamże na ten czas in the town they were beating and robbing Jews, their houses and synagogue, the latter was threatened to be zbuzyć y pomieniony ogrod do ostatka wniwecz obrocić. ...; pp. 155-156, no. 129, 5 March 1635 testimony of beadle regarding crushed Jewish tombstones, he writes that on 5 March byliśmy użytymi tu $w$ miescie Wilenskim od wszytkich żydow zboru miasta Wilenskiego do domu ych na przedmiesciu Wilenskim, za Wiliq leżacym, przy ogrodzie ych zydow, gdzie ciała zmarlych żydow chowaia, tam że za okazywaniem ych widzielichmy w ogrodzie ych żydowskim nad grobami deszek tablic pismem żydowskim ponapisowane, widzielismy wierzchi nakrycia tych tablic pozbiiano y posieczono, ktore swieżo na sniegu leżali; it is further noted that it is not clear who has done all of this. Concerning the events of 1634 also see Bershadskii, 'Istoriia', 1887, no. 4, pp. 75-77.

${ }^{20}$ AVAK, vol. XXIX, Vilnius, 1902, p. 25, no. 20, 15 Nov. 1669 the confirmation privilege of King Michał Wiśniowiecki which inter alia attested the rescript of Władysław IV dated 25 May 1642 ...do maystratu mieyskiego wilenskiego... aby szafarzom albo prowizorom szpitala Swientey Tróycy, na moście murowanym, ponieważ się żydzi na każda poprawę y budynek mostu szpitalnego znacznym datkiem przykladaia, aby gdy umartych przez most do kopiszcza swego prowadza, wrot zamykać y żadnych pieniędzy wyciagać nie kazali y nie dopuszczali, ale ich podtug listów y kwitów swych dawnych nienarusznie zachowali..; ibid., p. 389, no. 201, 15 March 1713 this privilege of 1669 was also confirmed by August II and on 29 May 1738 it was confirmed by August III (see LVIA, SA 4752, 1. 448-451); also see Klausner, Dzieje, p. 21; D. Frick, 'Jews and Others in Seventeenth-Century Wilno: Life in the Neighborhood', Jewish Studies Quarterly, vol. 12 (2005), no. 1, p. 36. 
processions for the benefit of the alms-house. ${ }^{21}$ However, already next year the Jews again persuaded the monarch to allow them to carry their dead across the bridge free of charge (as it used to be the case) and the document obtained by the parish priest of Holy Trinity Church was annulled. ${ }^{22}$ Klausner indicates that the Jews managed to obtain that charter because charging a toll on a dead person as a commodity insulted their religious feelings and deterred some of the mourners, which interfered with one of the key duties of Judaism, i.e. to accompany the deceased to the cemetery. ${ }^{23}$

During the Muscovite Occupation (1655-1660) many Jews fled the city but some of them returned to the dissatisfaction of Vilnius residents. Therefore, in 1658 sending their delegation to see the tsar in Moscow they requested among other things that he order all Jews to be evicted from the town across the Neris where their

${ }^{21}$ LVIA, LM 121, fos. 164-164v, Pewna pensia od Zydow Wilenskich na prowizia Proboszcza przy kosciele S. Troycy w Wilnie

Wtadystaw IV

Oznaymuiemy tym listem Naszym komu to wiedziec nalezy. Iz my uwazaiac szczupła intrate Szpitala ubogich w Wilnie przy Kosciele S. Troycy religiey Rzymskiey mieszkaiqcych ktorasie nie tylko na wyzywienie ubogich, ale y na poprawe Koscioła y Szpitala, na potrzeby y stugi Koscielne, na budowanie // y oprawe mostu na rzece Wiliey będace obraca, z teyze y Proboszcz przytym Kosciele y Szpitalu mieszkaiqcy, tak słaba ma prowiziq ze się zadnq miara onq wychowac niemoże. Przeto za wniesieniem do Nas imieniem ludzi ubogich y pomienionego Proboszcza prozby, poniewaz ny budowanie y naprawe mostu Wilenskiego na rzece Wiliey nie mało częsc prowentow szpitalnych obraca. A zydzi Wilenscy zatym mostem kopiszcze swe maiac y częste pogrzeby odprawuiqc, sine vllocensu przeiezdzaia y ciała umartych przeprowadzaiacych postanowic, iakoz tym listem Naszym postanawiamy y miec chcemy, aby za kozdq takq okazia ptacili po dwa złote Proboszczowi pomienionemu szpitala S. Troycy y successorom iego wiecznemi czasy. Co do wiadomosci zydom miasta Wilenskiego przywodzac, chcemy miec y rozkazuiemy, aby pomienione myto krom zadney contradictiey oddawali. Na co dla lepszey wiary ręka sie Nasza podpisawszy pieczęc WXL przycisnac roskazalismy. Dan w Warszawie dnia (space) mca' (space) roku Panskiego MDCXLVI...; also see: M. Paknys, Vilniaus miestas ir miestiečiai 1636 m.: namai, gyventojai, svečiai (Vilnius, 2006), pp. 50-51.

${ }^{22}$ AVAK, vol. XXIX (Vilnius, 1902), p. 25, no. 20, 15 Nov. 1669 the confirmation privilege of King Michał Wiśniowiecki which inter alia attested the rescript of Władysław IV dated 17 May 1647, ...J. K. mść serio napomina, aby żydów wileńskich przy zwyczayney quocie na poprawe y budynek mostu murowanego, od nich idqcey, wedtug pierwszego rescriptu y quitów swoich niepogladaiqc na list przez wielebnego proboszcza kościoła Swiętey Tróycy poślednia data wyniesiony, zachowali...

${ }^{23}$ Klausner, Dzieje, p. 21. 
cemetery was located. ${ }^{24}$ The instructions of 1669 of Vilnius for the delegation to the Election Seim indicate that the Jews begin settling in the suburb across the stone bridge as well. ${ }^{25}$

On 15 April 1663 a married couple from Vilnius, Alexander Lewicki and Ewa Zięcewiczówna, sold to representatives of the Jewish community an empty land plot without any structures (which used to be under ownership of the wife's parents Gygier Zięcewicz and Hanna Bogińska), located across the Neris for 80 Lithuanian kopy (threescore) of groats and described its boundaries (in between three other land plots, 39 sieksnis (one sieksnis/sqżeń measures about $1.95 \mathrm{~m}$ ) long and 24 wide, by the road past the Jewish land plots (the cemetery?) towards a brickyard. ${ }^{26}$ It is further maintained that the Jews may treat the land plot as they wish but they are to pay czynsz tax (rent) of 1 złoty and 15 grosz each year to the treasury

${ }^{24}$ Kraszewski, Wilno, vol. II (Vilnius, 1840), p. 125.

${ }^{25}$ AVAK, vol. X (Vilnius, 1879), p. 372, no. 86. According to Kraszewski a similar instruction for the town delegates was also prepared in 1676, see Kraszewski, Wilno, vol. III, s. 172.

${ }^{26}$ LVIA, SA 5361, fos. 31-32. Document dated 16 Apr. 1663. Zeznanie pana Alexandra Lewickiego y matzonka iego paney Ewy Grygierowny zydom Wilenskim... Na urzędzie JEo Kr' Mci'Drewnictwa Wilenskiego... do xiag Drewnictwa Wilenskiego wpisac kazałem... Ewa Zięcewiczówna po rodzicu moim nieboszczyku panu Grygieru Zięcewiczu i matce mojej pani Hannie Bogińskiej a ja wyżej mianowany Lewicki matżonek od mltki mojej plac ojczysty Grygierowski zdawna nazwany goty bez żadnego budynku $w$ Wilnie za rzeka Wilja $w$ pewnych granicach to iest // z iedney strony od Wilij placu niegdy JE Mci' pana Marcina Zeronskiego Chwalibogu w tyle y z boku iednego znowu tęz JE Mci' pana Zeronskiego a z drugiey strony placu nieboszczyka pana Jakuba Zienciewicza ktorego wzdluz klinem sqzni 39 a wszerz sażni 24 od drogi która idzie od Wilji mimo ogród Żydów wileń. ku ciegelniom zawilejskim pod jurysdyka derewn. wileń.... // ... A co się tknie czynszu do skarbu $i$ urzędu JE $E^{o}$ ' 'Mci' // Derewnictwa Wilenskiego w kozdy rok w dzien Sw'tego Michała swięta Rzymskiego złoty jeden y groszy Polskich piętnascie y wszelakie postuszenstwo jurysdyce swoiey ... Wypis wydany. This extract with certain inaccuracies referred to in the end was at the request of Jews entered into the castle court book of Vilnius Palatinate (administration of the town) on 30 November 1789 (LVIA, SA 4804, fo. 835) and published from there, see Klausner, Dzieje, p. 7 ir VI. A deed regarding installation of Jews in the acquired land plot was written there as well (LVIA, SA 5361, fo. 33 Intromissia zydom Wilenskim placu pod Drewnictwem. 15 Apr. 1663. In fact, the former owner of the land plot Grygier Zięcewicz died in 1647 and apparently his relative Jokub at that time acquired an adjacent land

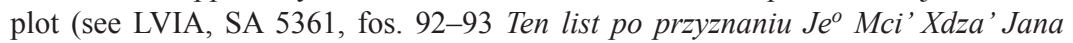
Czawidowsk Sobotnickiego do ksiag Derewnictwa Wilenskigo iest wpisane. 13 Apr. 1647. The privilege of the land plot of M. Zheromsky Chvalibog referred to in the text was written on 25 May 1647 into the LM Book 121, p. 190-191v. 
of the Castle Forestry Authority and along with others to discharge other duties mandatory for that territorial jurisdiction. There is data suggesting that in 1674 a land plot with a fence located near the cemetery and the river was bought for 300 złoty. ${ }^{27}$

The problem of carrying the deceased across the bridge persisted between the town and the Jews because a letter dated 1672 from the parish priest of Holy Trinity Church (which kept the alms-house supported from the tolls charged for crossing the bridge) mentions that, based on the old charters, the Jews could continue to carry their dead across the bridge free of charge. ${ }^{28}$ However, they were to accept voluntarily an obligation each year at Christmas and Easter to pay the priest 10 złoty and give a pound of pepper, ginger, rice, raisins and a pound and a half of saffron. The parish priest also undertook that nobody would interfere with Jewish funerals, although at that time the bridge, which had been burnt in 1655 during the Muscovite occupation, was not even rebuilt. ${ }^{29}$ Klausner has every reason to write that by his letter the parish priest admits that based on their privileges the Jews were not obliged to pay anything to him and doubts whether the Jews accepted such expenses of their own free will. ${ }^{30}$ The Jews were forced to accept such conditions because in 1756 at the request of their representatives that document was entered into the castle court book of the Vilnius voivodeship (palatinate). In the same year the said book received another entry, i.e. the 1685 document of King Jan Sobieski (the publication incorrectly indicates 1680 ) whereby the Vilnius magistrate and the heads of Holy Trinity Church were reminded inter alia that they illegally charged a toll of two złoty for carrying the Jewish deceased across the bridge and were ordered to cancel collecting unlawful duties. ${ }^{31}$ This was a result of the protest launched by the magistrate at court in 1684 where it disputed the said agreement of 1672 between the Jews and the parish priest and the commission formed to that end established that the agreement had been a personal matter between the parish priest and Jews and the latter had to pay 2 złoty from a

\footnotetext{
${ }^{27}$ Klausner, Dzieje, p. 7.

${ }^{28}$ Ibid, pp. 21-22 and X-XII (the document taken from SA 4768, fo. 332).

${ }^{29}$ Drèma, Dingęs, p. 376; see also AVAK, vol. X, Vilnius, 1879, pp. 395-404; J. Jurginis, V. Merkys, A. Tautavičius, Vilniaus miesto istorija nuo seniausiu laiku iki Spalio revoliucijos (Vilnius, 1968), p. 172.

${ }^{30}$ Klausner, Dzieje, p. 22.

${ }^{31}$ Idem, p. 23 and XII-XIV (the document taken from SA 4768, fo. 416).
} 
dead person for repairs to the bridge, yet if they wished to do so, they could transport their deceased by boats free of charge. ${ }^{32}$

In 1690 a list of buildings owned by the Vilnius synagogue mentioned three watchmen living in the Jewish cemetery. ${ }^{33}$ At the close of the seventeenth century a new neighbour appeared by the cemetery, i.e. a monastery of Discalced Carmelites funded by the Ogiński family with St Teresa's (some sources call it Holy Trinity) Church. ${ }^{34}$ In fact the Carmelites had received a permission from the ruler at the beginning of the century to open their brickyard on the Forestry land, where later a monastery was established nearby. ${ }^{35}$ Based on the extant donation of the land plot and its description, at that time the monastery did not have direct contact with the Jewish cemetery. ${ }^{36}$

${ }^{32}$ Zbiór praw i przywilejów miasta stolecznego W.X.L. Wilnowi nadanych, pp. 261, 263, 266; Kraszewski, Wilno, III, 1841, pp. 172, 341; Klausner, Dzieje, p. 22.

${ }^{33}$ AVAK, vol. XX, 1893, p. 481, no. 315, 31 July 1690, the list of buildings owned by Vilnius synagogue. ...Na kopiskach żydowskich za Wiliq stróżow trzech mieszkaiq. ... ; the same entry was published in $A V A K$, vol. XXIX, p. 201 and $M e-$ tryka Litewska. Rejestry podymnego Wielkiego Księstwa Litewskiego. Województwo wileńskie 1690 r., ed. A. Rachuba (Warsaw, 1989), p. 62.

${ }^{34}$ Podręczna encyklopedya kościelna, XVIII (1909), p. 348.

${ }^{35}$ LVIA, LM 119, fo. 667, no. 322 Confirmatia pewnego gruntu na cegielnie wielebnym oycom Karmelitom Bosym Wilenskim za murowanym mostym lezacego.

${ }^{36}$ LVIA, SA 136, fo. 437. August II's charter of 27 August 1698. Akt approbaty prawa donacyinego JXX Karmelitom Bosym konwentu Zawiley' stużcego: ...wieczystey donacyi zapis z intromissya od Przew' Bogu Eustachego Kotowicza biskupa Smolenskiego na plac..., do juryzdykcyi derewnictwa Wilenskiego należacy konwentowi Wilenskiemu oycow Karmelitow Bosych dany y rozne dokumenta za listem Nayiasn' Wladystawa IV ... otrzymane... // fo. 438 possessyi tychze wielebnych oycow Bosych turbowat... pisan w Lwowie...

fo. 439 Ducument dated 16 June 1647. Akt intromissyi dla JPP Grabowskich czyniony Jm'xięzy karmelitom Bosym Zawileyskim stuzqcego. ...Pawet z Brylewa Podchocimski horodniczy budowniczy y derewniczy Wilenski... wedtug przywileiu ... Wladyslawa IV ... w sprawie urodzonemu Jego m' panu Gabryelowi Kazimierzowi Grabowskiemu ...pewny plac z cegielniq takze ogrod sianozentka y sadzawka spustoszala y z piekarniq dla stroza w Wilnie za rzekq Wiliq nad sama rzekq tez Wilia $w$ pewnym ograniczeniu z iedney strony od gruntu y cegielni mieszczanina $y$ woyta Zamku Wilen' Ambrozeja Kabluka, a z drugiey strony od gruntu pana Marcina Zeromskiego ChwaliBoga // fo. 440 wedlug wysypania y ocyrklowania rowem. Koncami zas od drogi ktora od domow Zawiliskich do wioski Drewnickiey mimo cegielni mieszczanina Wielebney Kapituly Wilenskiey y Drewnictwa Wilenskiego Jakuba Ortowskiego alias Fiedorkowicza idzie a drugim do put rzeki Wilij będacey pod jurydykq JKm' Derewnictwa Wilen'lezacy, po smierci stawetnego pana Marcina Lewoncewicza spadty y conferowany. w posessya wieczysta z ktorego placu czynszu do skarbu JKm' Derewnictwa Wilen' ...w kazdy rok w dzien S. Michala... po złote 1 y groszy 7 y put pot ptacic maja...

fo. 441 Document dated 30 May 1647: Akt listu od NKM' Władysława IV od JP Hor' pisanego dla podanie placu JPP Grabowskim ...XX Karmelitom Zawileyskim stuzqcego. 
In the early eighteenth century, due to the various rigours shaking the town and the country and a general recession, expansion of the cemetery apparently came to a halt. The outbreak of disasters seemingly created a situation whereby in 1704 due to unclear (yet most probably financial claims) there were attempts to expropriate the Jewish cemetery land together with a part of a stone building in Žydu Street. Although a judge's marshal went to the cemetery, he somehow applied the court ruling only to the stone building. ${ }^{37}$ In March 1710 at the outbreak of plague, a universal decree of Ludwik Pociej, the grand hetman of the GDL ordered people not to obstruct Jews burying their deceased in the land plots they had acquired across the Neris because a great number of dead people accumulated in households and an epidemic might break out. ${ }^{38}$ One case of 1740 between the Jews and the Austin friars mentions that the fire of 1723 in the Jewish neighbourhood in Vilnius destroyed many documents they had concerning the cemetery plots. ${ }^{39}$ Furthermore, the Jews of Vilnius in their complaint to the Russian authorities in early nineteenth century report breaches by the Holy Confraternity

${ }^{37}$ LVIA, SA 4719, fo. 97 (original, fo. 98 copy), Document dated 7 Febr. 1704. Ja jenerat JKMsci'... zeznawam tym moim intromissynym podawczym kwitem iz roku teraznieyszym ... byt uzyty y postany od wielmoznego JEMsci pana Kazymierza Wołowicza sędziego Ziemskiego Wilenskiego dla podania pierwiey mogił Zydowskich za Wiliq Murowanym mostem a potym drugiey połowicy kamienicy Kiernowickiey nazwaney na Zydowskiey ulicy za dekretami sqdu Głownego Tribunatu WXL dabo w nych wyrazonych a mianowicie za dekretem... z aktoratu JEMsci pani Zofij Dzierszkowny Jakubowey Skalskiey y stolnikowey Czernihowskiey otrzymanym y za sume wtych dekretach wskazano y na odprawe do niewiernych zydow...odestano ...oddac zesłat gdzie ia jenerat przybywszy do pomienionych Mogit za Wilia Murowanym mostem będacych a potym do drugiey połowicy kamienicy Kiernowickiey strona szłachty podalem druge połowice tey kamienicy z wszytkiemi ...mieszkaniami $y$ rocznym czynszem... $w$ moc dzierzenia y spokoyne uzywanie.. podalem...

${ }^{38}$ AVAK, vol. XXIX, 1902, p. 347, no. 188, 1 March 1710: ...prezentowane mi byly od naiaśnieyszych królow Ichmć antecessorów in genere, żydom WKL nadane y konstitucyami seymowemi confirmowane na wolności kopiszcz, na grzebienie umartych ciat żydowskich, do którego przywileiu stosuiqc się, biore pod protekcia y obrone moiq placy albo grunty na te kopiszcze przez żydów Wileńskich nabyte, za rzekq Wilia, $w$ Wilnie będqce...; also see Klausner, Dzieje, p. 11.

${ }^{39}$ LVIA, SA 4752, fo. 1146, ... na ktore place y dokumenta posessyi od roznych iurysdatorow y aktorow mieli sobie podawane, a że takowe dokumenta pod czas publiczney miasta J.K.M'ci Wilna konflagracyi w roku 1723 naybarziey około ulicy Zydow y Jadkowey zaczowszy od kamienicy Bryna cyrulika w Wiliq So Jana trwaiqcey u żydow starszych mogit $w$ domu będace przy znaczney substancyi tak jako y drugim obywatelom Wilen' pogorzeli, o czym process in tempore zaniesiony swiadczy... (for this reference I am grateful to Domininkas Burba). 
(Chevra kadisha) which tended the cemetery and buried Jews. In addition, the complaint mentions that all the old documents of Vilnius Jews, including the cemetery documents were destroyed by fire of 23 June $1723 .{ }^{40}$

Regrettably interference with Jewish burials did not end. The castle court book of Vilnius registers an incident in early October 1726 when a dead Jew was carried without a procession past St Catherine's Church and the Benedictine Nunnery towards the cemetery in a cart driven by a Christian. ${ }^{41}$ The priest came to the street and with the help of others seized the cart with the deceased. When at the request of the Jews the bishop demanded it be given back, the furious priest threw the body into a puddle in the square where it lay all day and all night since the priest attacked everyone who tried to pick it up with stones. Klausner was probably right claiming that

Obviously the reason for the priest's rage was the fact that he could not receive a tax paid by funeral processions. Seeing a simple cart driving quietly by with a Christian coachman, the priest suspected an attempt to carry the dead person secretly without a fee, which he considered a rightful charge of the nunnery. Such instances when carts with the deceased were stopped were frequent. In 1804 on her way home from the cemetery a Jewish girl, Esther, the daughter of Rabbi Eliezer was even killed. ${ }^{42}$

Irrespective of royal charters, from time to time further obstacles were posed for Jewish funeral processions to cross the bridge as unlawful charges were demanded. In 1749 a decision of the Treasury Tribunal of the GDL was received stipulating that pursuant to documents of 1633 and 1742 the Jews had no obligation to give money for repairs of the bridge and other needs of town residents, but only to pay the set amount each year. ${ }^{43}$ Apparently, the situation did not change much, as in the beginning of 1757 an agreement between Vilnius wójt and the Jews was made regarding conditions of transporting the deceased across the bridge.

${ }^{40}$ LVIA, f. 1135 , ap. 4, b. 417 , fos. 20v, here (fos. 19-30) the history of the cemetery confraternity (burial society) is also described and 19 clauses of its bylaws are listed (indicated by Vytautas Jogèla).

${ }^{41}$ Klausner, Dzieje, p. 19-20; LVIA, SA 4752, fos. 685-686: Akt dekretu kasystorskiego zydom Wilenskim stużacego.

${ }^{42}$ Klausner, Dzieje, p. 20.

${ }^{43}$ Ibid., p. 23; LVIA, SA 2689, fos. 259-260. Document dated 19 Sept. 1749: Dekret miedzy JP Pietkiewiczem instygatorem Trybun'Skarbowego WXL z niewiernemi zydami Wilenskiemi. 
Referring to charters of rulers Władislaw IV and Jan Kazimierz, Mychał Wiszniowecki and Jan Sobieski concerning carrying the dead across the Neris bridge free of charge, it was finally agreed to introduce a toll of 1 tynf (30 groats) from the dead body and its eight accompanying people. ${ }^{44}$

In 1739 the Radziwiłl had claims to the Jewish cemetery territory as they had considerable estates nearby in Šnipiškès and demanded a payment for it but unlike the Jews, failed to provide documents proving their title to the cemetery land and had to settle only with an increase of the payment for patronage offered by the Jews. ${ }^{45}$ Evidently due to the fact that in 1740 the GDL Cupbearer Hieronim Florian Radziwiłł had ordered stewards of his estates in Vilnius and Šnipiškès that he as well as his forefathers would protect Vilnius kahal cemetery located in Šnipiškès and the kahal for his grace would pay as they used to 40 złoty from the cemetery ( $z$ kupisek) each year. ${ }^{46}$ A year later Vitebsk Palatine Marcijan Oginski also solved a dispute regarding boundaries and the fence of the cemetery between the Discalced Carmelites he endowed and the Jews in favour of the latter and ordered monks to patronize the Jews, who in return had

${ }^{44}$ AVAK, vol. XXIX, p. 451-452, no. 225.

${ }^{45}$ Klausner, Dzieje, p. 17-18; LVIA, SA 4754, fo. 748. Document dated 15 dec. 17939: ... Na urzędzie JKmci' Grodzkim Wilenskim... tym moim testimonialnym pismem iż $w$ roku teraznieyszym... Jm pan Zubowicz komissarz y Jm' pan Narwaysz ekonom juryzdyki Wilenskiey y dobr Je Xięzney Jeymci' Radziwiłłowey kanclerzyney $W$ WXLitt' intentowali byli akcya z Kahatem Wilenskim ...we dwuch punktach idq' $w$ pierwszym punkcie o pogrzebiszcze zydowskie pretenduiqc ażeby zydzi ztego pogrzebiska płacli większa sume do skarbu JO Xięzney Jeymci' aniz dopiero $i$ że to ten grunt mogit zydowskich za Wilya sytuowanych nalezy do xięzney Jeymci' mienili. W drugim punkcie o rzeznice zydowska Snipiszczanska pretenduiqc a zeby kahat Wilenski certum quantum od rzezi bydta płacit do skarbu xięzney Jeymci'. Zydzi zas kahatu Wilenskiego personaliter stanowszy przedemna ...czesnikiem y podwoiewodzym Wilenskim naypierwiey doprassali się ażeby tak Jmc' pan // Zubowicz komisarz iako Imp Narwaysz ekonom... pokazali naprzqd dokumenta na pismie z aktoremi pretenduiq y pociagaiq doptacenia większych importancyi na co innych dokumentow niepokazali jak tylko inwentarz. E contra zas zydzi Wilensci produkowali abjurate mogiłek swoich przez zydow Wilenskich w roku 1690 dymow 3 także przywileie krolow Ichcw' rescripta y inne dokumenta kupli swoich na tych placach mogit zydowskich na wieczność stużqcych, a Jasnie oswieconey Xięzney... tylko za protekcyq waznq panskq s przystugi intrate czynili... pisan $w$ Wilnie...

${ }^{46}$ Klausner, Dzieje, p. 17 and XV-XVI (the document published from SA 5348, fo. 979$)$. 
to present gifts to them at Christmas and Easter, ${ }^{47}$ though the Jews were already paying land, and other taxes for the cemetery plots located in the castle warden's lands. ${ }^{48}$

In 1740 a dispute with the Austin friars arose concerning their intention to construct a building near their brickyard in front of the gate to the Jewish cemetery and seize an opportunity to expropriate one of the land plots at the cemetery because (apparently in 1723) the documents of the land plots acquired by the Jews were destroyed in a fire. The case mentions that the Jews had bought land plots near the cemetery but around the location brickyards of different owners were established. ${ }^{49}$ The dispute seemed to be solved when the Jews

${ }^{47}$ Ibid., p. 12 and XVI-XVIII (the document published from SA 4754, fo. 750 ... ponieważ dokumenta przez Żydów remonstrowane objaśnili doskonale, że iuste tymże Żydom ten grunt mogitkowy należy i parkany na granicach własnych ich stoja ...).

${ }^{48}$ LVIA, SA 4248, fos. 608-609. Document dated 16 Sept. 1733: Akt kwitow stuzqcych Zydom starszym Wilenskim.

...Na urzędzie Grodzkim Wilenskim... personaliter niewierny zyd Litman Moyzeszowicz obywatel Wilenski kwitow pięc sobie y drugim zydem starszym Wilenskim stuzacych ad acta podat $w$ te stowa pisane. Imo Roku 1731 zydzi starsi Mogit oddali nalezqce Terragium złlotych szesc z kturego oddania kwituiqc podpisuie sie pisan // w Horodnicstwie miesiqca septembra 30 dnia p. Kazimierz Zagorski P.H.W. 2 do 28 Sept. 1731: ...starsi zydzi Bractwa z Mogit swych nalezqco Hiberne podtug przeszłych kwittow oddali złotych szesc... 19 Sept. 1732: 3. starsi Bractwa Synagogi Wilenskiey oddali podatku Hibernowego złlotych szesc... 4. 20 Sept. 1732: starsi Bractwa // (fo. 609) oddali Terragium złlotych szesc... 5. 17 March 1733... starsi zydzi Synagogi Wilenskiey Hybernowego podatku z Mogitt swoich za Wilio do Horodnictwa nalezacych wypłlacili in toto złlotych szesc podtug kturego odebrania kwituiqc podpisuię sie p. Kazimierz Zagorski PHW...; and in 17398 złoty were paid as hyberna tax for the cemetery, see V. Drema, Vilniaus namai, book XII, p. 44.

${ }^{49}$ LVIA, SA 4752, fo. 1146-1146v. Document dated 27 Oct. 1740: Process Zydow Wilen' na Ichm' XX Augustyanow. ... Na urzędzie J.K.Mci' Grodzkim Wilen', ...załowali y solenniter manifestowali się niewierni ...żydzi starsi Bractwa Mogił żydowskich, w miescie J.K. Mci' Wilnie za rzekq Wiliq miedzy cegielniami sytuowanych, nomine calego kahatu tu Wilen' na... Proboszcza y wszystkich w Bogu wielebnych Ich'w XX Augustyanow w Wilnie na Zarzeczu rezyduiqcych, mieniac o to iż $w$ żaltce' deltory żydzi kahatu Wilen' maiqc rozne place od roznych osob zdawnych czaśow nabyte in circuitu mogit dawnych żydowskich za Wiliq między roznemi cegielniami będace, ... tedy obźattni' Ichmc' xięża Augustyanie Wilen' maiqc plac swoy pusty dotad z murkiem przy cegielni swey podobno niedawnymi czasy erygowaney ex opposito samych wrot mogit żydowskich bokiem, a frontem alias wroty ma jako sq znaki do drogi starey poprzeczney od mogit żydowskich ku Werkom ciagnqcey y na przeciw placu pustego dettw' qvondam od należytych aktorow nabytego sytuacya swa maiacy pod pretextem wiadomosci że dokumenta dettw' na te place wszytkie pogorzeli, plac Immediate pomieniony dettw' w bliscie 
also bought the land plots of the monastery since a transaction of a land plot purchase from two tenants of the Austin friars upon expiry of the rent period in the Castle and Forestry Authorities' lands near the cemetery was registered in $1743 .{ }^{50}$ Interestingly, both sellers could still live in the houses they had built until expiry of the rent agreed with the monks, but the Jews already had the right to use the land plot (for burials?). Furthermore, in 1738 the inventory of the Castle dependent land mentioned that 6 złoty would be paid

teraz zostaiqcy ex opposito placu takoż pustego Ichw' pomienionego, gdzie teraz przy dawnym starym murku na przeciw wrot mogilnych żydowskich budować zaczynaia // będqcy, ultro do onego wdzieraiqc się, per vim odebrac usituiq, takoż $w$ roku terazn' 1740 m'ca octobra 27 dnia za uproszeniem przyiaciot ab utrinque, y za ziachaniem pro cognitione ad fundum, z samych dokumentow Ichw', a mianowicie z prawa kupnego Ich'w na plac Ich'w stuźqcego, y z ograniczenia dettw' w protestacyi in tempore zaniesioney y stawionych swiadkow palpabiliter pokazatasie legitimitac posessyi placu pomienionego deltw' a obzaltni Ich 'ie non attenta patetica deductione, per vim ac per potentiam, a prawie solo apetitu wodzcy ubogich żydow ziemi pochwatki publiczne przed temuż przyiaciołami na wyiazd y kognicya użtemi, nietylko odebraniem tego placu dettw'y pobudowaniem swoich budynkow, ale etiam y na życie samych dettw' uczynili, zaczym żattce' dettres' uciekaiqc się do zwierzchnosci sqdowey, a chcqc o to jako się wyzey wyraziło z obzattmi' Ichm'mi iure prosequi, ante omnia ab ulterori obzaltch' Ich'w impetitione et violentia, respektem wdziałanych pochwałek, securitatem posessyi pomienionego placu pustego deltw' na przeciw rogu parkanu mogit Zydowskich miedzy cegielnia Bernardynska a płacem Ich'w z murkiem na nim będqcym leżacego niemniey securitatem życia y zdrowia przez decyzyq sqdowa przy aprobacii protestacyi in tempore o pogorzenie dokumentow zaniesioney referuiqc się do ograniczenia we własnych dokumentach obzattch' Ich'w y drugich posessorow okolicznie tego placu graniczacych nayduiacych się, takźe do swiadectw ludzi wiadomych, warować, paen, szkod y expens prawnych, oraz y tego wszystkiego co kolwiek iuris ac praetensionis bydz może, a czasu prawa fusius przez kontrowersya Ich'w pp'w patronow et ex documentis takźe y swiadectw ludzi wiadomych deducetur dochodzic y requirować, salva melioratione tey żałoby, dettres', na obzatt'ch Ich'w, dali tę swoiq protestacya do xiag Grodzkich Wilen' ku zapisaniu. Co iest zapisano.

${ }^{50}$ Klausner, Dzieje, p. 7; LVIA, SA 5128, fo. 811. Document dated 20 Dec. 1743 ...comparenses personaliter honesti Andreas Baranowski et Simon Kudzinowicz laterifices cives Viln'... recognoverunt. Iz oni mieszkaiqcy domami swemi na placach Ichcw'XX Augustyanow Zarzeckich Wilenskich ad expensa Synagodze zydow Wilen' jura perpetua ... y przedanych za rzekq Wiliq $w$ pewnym swoim ogroniczeniu przy mogiłach zydowskich pod juryzdykq JKM Horodnicstwa Derewnicstwa Wilenskiego lezacych niemaiq zadnego prawa akcessu y przystęu do pomienionych placow ad psens'zydom Wilen' przedanych, tylko swoie domki przez siebie zabudowane w ktorych // do terminu w kontraktach od Ichcw' XX Augustyanow sobie danych wyrazonego, maia pacifice mieszkac. A po terminie ze wszystkim powinni z tych placow rugowac się, quod est commotatum. 
for two land plots joined to the Jewish cemetery. ${ }^{51}$ Apparently the situation of the first half of the eighteenth century where several land plots are seen in the place of the cemetery is reflected in the so-called Fürstenhof Map.

After 11 years a misunderstanding between the castle warden and Vilnius Jews occurred most likely due to the same two land plots and another one. On 4 May 1754 Vilnius castle warden Mychał Horain informed the kahal that at the request of the Jews to expand the cemetery it had been allowed to acquire two land plots from the Austins, one land plot in front of the cemetery, the second land plot in front of the small gate as well as the third one closer to the river bank and already surrounded with a fence with stone posts and without a right to erect structures on them. However, since the land plots across the road would be required for the expansion of the cemetery only in the future, he did not expropriate them from the Jews but in order not to keep them empty he allowed brick-makers to begin constructions, undertake their trade and pay 4 złoty from each of the three houses. In addition, whenever the Jews needed to expand their cemetery, those residents would have to destroy their houses and cede the place to the Jews. ${ }^{52}$ The Jews were obviously once bitten, twice shy because sometimes the Castle officials tended to line their pockets demanding additional payments from the Jews

${ }^{51}$ E. Łopaciński, 'Horodnictwo Wileńskie w latach 1470-1794', Wilno, kwartalnik poświęcony sprawom miasta Wilna, rok I, 1939, no. 2, p. 80.

52 LVIA, SA 5132, fo. 1433 ... Iz ja horodniczy Wilen' ... pozwolitem na rozpostrzenienie ich mogit dwa place od Ichmcw' XX Augustyanow nabyte, jeden na przeciwko wrot, drugi na przeciwko fortki mogilnych, trzeci do brzegu Wiliy pociagniony y iuz parkanem $w$ stupach murowanych zarzucony, ...y do ufundowania jakiey kolwiek juryzdyki edificia, aby ciz pomieniony kahałow // starsi nullo sibi jure aliquam potestatem przy własczac mieli zabronitem, lecz kiedy po otrzymanym odemnie konsensie, ciz zydzi do nim comparuerunt, iz dorzczc niepotrzebne tych placow lezacych przez droge do mogit przyięcie bydz opowiedzieli, lecz tylko ad futuram rozpostrzenienia swoich mogit necessitatem konsens odemnie in adamplificationem mogit otrzymali, więc Ja Horodniczy aby te place sterriliter przez siła nastęuiqcych lat odtogiem niędznim (?) (nihil praeiudicando pierwszemu konsensowi moiemu, ktory nalezyte aktorstwo zydow do tych nabytych placow przez nich ze samych, zapozwaleniem moim utwierdza) Pracowitym strzycharzom, na tych placach $w$ domach y cegielniach budowac się pozwalam, ...poki ze futuro zydowskiey potrzeby tempore na rozpostrzenienie ich mogit potrzebne sie niepokazq skoro by zas ta ingruas potrzeby kahalu nastapiła, tedy bez zadney odwtoki exkuzy y racyi pomienieni mieszkance domy swoie cum integra superficie znosic obligowani $y$ powinni będa, ...tedy zas y poty poki ich // edificia na tych ze placach odemnie zydom pozwolonych subsistant z kozdego domu po złotych $4, \ldots$. 
for land plots of the Jewish cemetery located in their jurisdiction. Therefore, the Jews did not believe those promises and took action described in the Jewish chronicle of the Holy Confraternity (Chevra kadisha):

Given the time of trials for the Jewish community, when the enemies have destroyed the wall surrounding the community cemetery, eight members of the Holy Confraternity and its treasurers have decided that the latter will pay to his grace Horain the requested amount, but not more, and will not accept any more demands. ${ }^{53}$

For an annual land tax of 12 złoty and based on permits issued by former Castle officials (specifically mentioning Kotowicz ${ }^{54}$, obviously referring to the land plot purchases of 1663 and 1674) the castle warden promptly revoked his application to the court, merely demanding that the Jews would not erect any buildings on those land plots and use them for the cemetery only. ${ }^{55}$

In 1758 at the request of the Jews, the joining of land plots located on Castle Authority land to the cemetery as a possession in perpetuity was officially legalized by a court official of the GDL and the land plots measured (measured $11 \times 24 \times 13 \times 10$ rods (prety) and the other measured 5.6x26x26x4.4). Judging from their description they bordered the cemetery in its upper section (in the direction from the river). ${ }^{56}$ It should be noted, however, that only two land plots

${ }^{53}$ Klausner, Dzieje, p. 8.

${ }^{54}$ Andrzej Franciszek Kotowicz, Vilnius castle warden (horodniczy), forester, builder in 1657-1682 and a castellan in 1672-1682, see Urzędnicy Wielkiego Księstwa Litewskiego. Spisy, vol. I: Województwo Wileńskie XIV-XVIII wiek, ed. A. Rachuba (Warsaw, 2004), nos. 190, 307, 337, 393.

${ }^{55}$ Klausner, Dzieje, p. 8-9; LVIA, SA 5132, fo. 1437. Document dated 22 May. 1754: (the old page number was 1451) ... na ktorych to placach procz własnego kopiszcza nic innego niemieli juryzdyki nullo praetextu nieformowali żadnego zabudowania niezaktadali, ...ktore to place tym sposobem opisuiq się to iest na przeciw forty mogilney ku mostowi przez droge do Wiliy ydac także plac cum konsensu urzędu Horodniczego od Ichmcw'Xięży Augustyanow Zarzeckich Wilenskich nabyty przyiezdzaiac droge od ich Ichmcw'Xięży Bosakow Zawileyskich przeciwko wrot mogit Zydowskich sytuowany tudzież // plac od Wilij przy mogiłach od Jmci'xiędza plebana Wilenskiego stupami teraz murowanemi y dylami zarzucony z których to placow y mogyt poziemnego tyle powinni płacić na rok po złotych 12 ...spod juryzdykcyi Horodniczego wyłamywać się niebęda mieć mocy owszem równo z drugiemi do Horodniczego fundum przystuchaiacemi należeć y onego juryzdykcyi podlegać powinni będa ... $w$ Wilnie...

${ }^{56}$ Klausner, Dzieje, p. 9 and XX-XXII (the document was published from SA 5363, fo. 22)... po wymierzeniu i ograniczeniu tychże dwóch placów przez 
were mentioned there, but obviously the two land plots acquired from the Austin friars were joined into one.

In the same year of 1758 a letter was received from the Castle forester Ludwik Abramowicz confirming that the Jews had acquired two land plots in the forestry land from residents of the said dependent land. It furthermore stated that presently those two land plots with the cemetery were surrounded by a fence with stone posts and the Jews had to pay a czynsz tax of 12 złoty per year and an additional hyberna tax (for the upkeep of the army during winter) as they always $\operatorname{did}^{57}$.

In 1772 fishermen living on the land of the castle warden attempted to take over the section of the Jewish cemetery lying along the river, which apparently had not yet been used for burials. They tried to store firewood and other items, but when the Jews called the fishermen to the court of that territorial jurisdiction, the latter failed to prove their title to the land in question. Meanwhile the Jews referred to the said decisions of Castle Warden Michat

tenże urzqd horodnicki idque jednego naprzeciw forty mogilney, który w takowym ograniczeniu zostaje, to jest: od rzeki Wilji idque w górę ku mostowi murowanemu tyłem leży do ciegielni u Bogu wielebnych Jchmw XX Jezuitów Nowicjackich ma w sobie wszerz prętów 11 bokiem jednym do kopiszcza tychże Żydów wileńskich starodawnego $i$ wrót nowo teraz postawionych $i$ stupów murowanych, wzdtuż prętów 24, a drugim bokiem do drogi, która idzie od Wilji rzeki y różnych cegieleń w pole po gline wzdluż prętów 13 przodem do rzeki Wilji i do dróg ku murowanemu mostowi idacych $i$ wrót mogilnych teraz nowopostawionych i stupów murowanych prętów 10; A drugiego placu naprzeciw wrót mogilnych od Jchmw XX Augustjanów przez tychże Żydów wileńskich nabytego, którzy także w takowem ograniczeniu najduje się, to jest: tylem leży między drogami, jednq do derewnictwa, a drugq do klasztoru Jchmć XX Bosaków; Ma w sobie wszerz prętów 5 y łokci 6, bokiem zaś jednym do kopiszcza alias mogit żydowskich starodawnych $i$ wrót teraz nowo postawionych mogilnych i stupów murowanych wzdluz prętów 26 a drugim bokiem do drogi do derewnictwa idqcej i pola prętów takoż wzdluż 26, przodem zaś leży między drogami jedna z derewnictwa do murowanego mostu a druga $z$ mogit żydowskich do tegoż mostu idqcymi ma w sobie wszerz prętów 4 i łokci 4 do nienarusznej spokojnej wieczystej possesji ... podałem, intromittowatem i do ich mogit przytaczytem...

${ }^{57}$ Klausner, Dzieje, p. 10 and XXIII-XXIV (the document was published from SA 4804, fo. 834), ... iż ja derewniczy w-a wileń. majac place derewnickich dwa na mogiłach żydowskich, które teraz stupami murowanemi i między stupami parkanem oparkanione na nich $w$ wlasnych granicach wedtug dawnych ograniczeń inwentarzów derewnickich ab antiquo nabyte a do mego przystuchu należqce,... owszem dawne ich prawa kupne aprobuje... a pomienione Żydzi kahat wileń. Maja censum płacić z placów tak horodnickich jak $i$ derewnickich po złtch 12 rate hyberny płacić do skarbu Rzplitej wedlug dawnych czasów. ... 
Horain dated 1754 and 1758, thus, Castle Warden Anton Towiański threatening with prison and fines prohibited occupying the territory of the cemetery. ${ }^{58}$

The Jews continued buying additional land plots for the cemetery. For example, on 19 October 1773 Towiański in the court book of the castle land registered a deed of the elders of the Jewish burial society stating that in July they bought a land plot named Krukiszki from the parish priest of St John's Church which was located in the land of the castle warden and was near Carmelite St Teresa's Church. ${ }^{59}$ The Jews undertook to pay the land tax and hyberna tax

${ }^{58}$ LVIA, SA 4217 Protokut spraw horodnickich Wilenskich... fo. 43 R'u 1772 m'ca maia 19 dnia $w$ sprawie niewiernych zydow ... y całego kahatu Wilenskiego z Geydemowiczem y Symonowiczem oraz Giełazewskim rybakami na Horodnictwie za rzeke Wilio mieszkaiqcemi o zubieranie brzegow, suchych, do kopiszcza zdawnu placow przynalezacych o sktadanie drew, blechow zuzywanie y o inne dyspotyczne wdzieranie sie y przeszkody czynione a do tych ze placow prawami od dawnieyszych WW JPP Horodniczych nadanemi y opisanemi, y intromissyami juryzdycznemi ograniczonemi. Poniewaz, ci wyz rzeczeni juryzdyczanie horodniecy ...zadnych na te brzegi niepokazawszy dowodow, tylko abusive przywłaszczaiac daley zazywac uporczycie domuwiali się. A starsi bractwa Mogit zydowskich poktadali przedemno Horodniczym konszens $w$ Bogu zeszłego W'o. JP. Michała Horaina horodniczego na ten czas e' in post podkomorzego w'a Wilen', sub anno 1758 y od dawnieyszych predecessorow 1754 ktore tak oryginalne, z extraktami tych ze aktow horodnictwa Wilenskiego z intromissyami juryzdycznemi wyięte prezentowali, bez zadney na ten czas ni od kogo przeszkody y rekłamaty, ci zas rybaci de super wyrazeni gotosłownie tylko ze im brzegi potrzebne domagali sie, przeto uchyliwszy onych niestuszne y niesprawiedliwe domaganie się, a skłoniwszy się do sprawiedliwosci Swiętey, ...// Ktore mocq urzędu mego one aprobowawszy, in toto ac per totum et circa in violabilem possesionem starszych mogit zydowskich na zawsze zachowuię. Zadney prepedycyi od pomienionych rybakow, ...niezachowuię. O wszem przy wszelkiey pomienionych kahalnych wolnosci moco konsensow onych, niwczym nienarusznie a podtug ich wolney dyspozycyi autoritate mea utwierdzam y ubespieczam. Na przeciwnych zas y przeszkode czyniacych penam sesionis turris, albo turmy niedziel dwuch y piędziesiat kop litewskich kahałowi, a drugie piędziesiat kop groszu litewskich sqdowi horodnickiemu zapłacenie zakładam, oraz wieczne od tad milczenie wszytkim intruzyq czyniacym nakazuie...

${ }^{59}$ Klausner, Dzieje, p. 10; LVIA, SA 4217, fo. 51. Document dated 31 Jully 1773: ...Na urzędzie JKmci Horodnickim ...danym na kupienie placu y z zabudowaniem na nim za rzeko Wilie blisko koscioła S. Teressy na rogu ulicy od Wilij do gury przy kopiszczu zydowskim idqcey, quandam Krukiszki zdawna nazwanym przez Jana Andrzeiewskiego dawniey zabudowany, a przez w Bogu przew' Jmci'X'a Michała Alexandrowicza..., z zabudowaniem na nim y z ogrodem $w$ swoiey cyrkumferencyi będacym, ktory to plac za władza sobie od N'o Krola Jmci'y Rzeczypttey', oraz a zeby censum do horodnictwa w'a Wilenskiego podtug ustawy komissyiney dwuma ratami to iest marcowa y septenbrowa co wynosi na obie raty poziemnego $y$ hybernowego $z$ szosowym złlotych 12 y groszy $24 \ldots$ Pisan $w$ Wilnie... 
totalling to 12 złoty and 24 groats per year. The priest had acquired the said land plot only three months ago from successors of the former owner Andzejewski. Apparently there were a few derelict buildings on the land plot which bordered the Jewish cemetery and most probably used to be in the ownership of fishermen because along with the land plot a customary right to fish was transferred to the buyers. ${ }^{60}$

After two years the Jews bought the neighbouring homestead with all its structures and a fence on the river bank from Symonowicz, who might have been one of the three fishermen attempting to take over the cemetery land three years ago, and paid the former owners 950 złoty. ${ }^{61}$ The land plot was also located on the land of the castle warden. In 1777 the Jews acquired a new land plot already from another resident in that jurisdiction. ${ }^{62}$ The Jewish chronicle of the Holy Confraternity contains an entry that in 1783 a large land plot by the cemetery is bought from Bishop Massalski and a testimony dated 1791 that the Holy Confraternity had to deliver a

${ }^{60}$ LVIA, SA 4221, fos. 537-540. Document dated 17 April. 1773: Zeznanie inwentarza na dworek $w$ Wilnie za Wilia na horodnictwie JX. Alexandrowiczowi komendarzowi Wilenskiemu So Janskiemu stużacego; fos. 541-544. Document dated 19 April 1773: Intromissya na dworek Krukiszki za Wilia na Horodnictwie JX Alexandrowiczowi stuzaca.

${ }^{61}$ Klausner, Dzieje, pp. 10-11; LVIA, SA 4222, fos. 1871-1874 (the old page was 27) Document dated 2 Jan. 1775; ...Na rokach stt' Trzybunalskich ziem' $w$ Wilen'... My Kazimierz y Krystyna z Markiewiczow Symonowiczowie obyw' miasta JKm' Wilnie ...// ... vigore konsensu w r'u 1765 ...na plac do zabudowania nam wydanego dworek na Horodnictwie Wilen': za rzekq Wilia przy mogiłach zydowskich sytuowany de proprio erygowawszy y do daty ninieyszey $w$ aktualney dzedzicniey w spokoyniey possessyi przez nas dzierżany ze wszelakim zabudowaniem obszernosciu rozległosciu brzegiem Wilii zdawna do tego dworku należqcym a $w$ takowym ograniczeniu zostaiacy to iest fratem do Wilii rzeki, tylem do mogity zydowskiey bokiem iednym do dworku Zakowskiego rybaka drugim bokiem y dworku y placu zydow kahatu Wilen' od JX Michata Alexandrowicza komendarza koscioła parochialnego Stt' Janskiego prawem wieczystym nabytego leżacy ... lecz ze wszytkim // zabudowaniem drewnianym parkanami sklepem murowanym owo zgoła zewszystkim iak się ten dworek ad priesens $w$ sobie znayduiq... za summę rękodaynie wzięta y odliczona zlt' plch'950... starozakonnym zydom ...// ... Pisan $w$ Wilnie ...

${ }^{62}$ LVIA, SA 4217, fo. 58: Roku 1777 meca' juliy 3 d'stanowszy osobiscie przed aktami urzędu JWm'Horodnickiego wo 'dztwa Wilen' uczciwy Jerzy Jancewicz rybak y obywatel juryzdyki horodnickiey Wilenskiey prawo wieczysto predazne y zrzeczne na plac za Wiliq na horodnictwie Wilen'sytuowany za summe 19 czerwonych złotych starozakonnym ... starszym Mogitkowym y całemu kahałowi w osobie swey y zony swey przyznat. Przyznalem +++(so signed) Jerzy Jancewicz. 
huge amount of money promptly for the cemetery purchase from the Christian. ${ }^{63}$ After a year the Holy Confraternity decided to acquire one more land plot and in 1803 they negotiated the amount of money necessary for additional lands, regarding which they had to litigate against neighbours, Bernardine friars, who had a brickyard nearby. ${ }^{64}$ Acquisition of lands for the cemetery expansion required significant efforts and costs from the Jews.

Thus, Vilnius Jews at different times used to buy land plots around their cemetery on the dependent lands of the Vilnius Castle and Forestry Authorities and in this manner expanded the territory of the cemetery. Moreover, in the second half of the eighteenth century in the said dependent lands, which were often ruled by one authority, disputes arose concerning 4 land plots joined to the Jewish cemetery, for each of which the Jews had paid 100 złoty. ${ }^{65}$

Disputes regarding accompanying the Jewish dead to the cemetery across the Green Bridge continued. On 18 January 1757 an agreement between Vilnius wójt and the Jews was made stipulating conditions of carrying the deceased across the bridge. ${ }^{66}$ Taking into consideration the privileges granted by Władysław IV and Jan Kazimierz, Michał Wiśniowiecki and Jan Sobieski regarding free carriage of the dead across the bridge over the Neris, a mutual agreement was reached to introduce a fee of one tynf from a dead person and 8 accompanying mourners.

Since conflicts with neighbours concerning the cemetery boundaries used to arise constantly, as it has been noted above in 1741 Ogiński attempted to establish the cemetery boundaries in Šnipiškès with the Discalced Carmelites he supported. The latter seemingly agreed with his decision but not for long. According to Klausner the Holy Confraternity of Vilnius Jews already in 1674 and later (in the eighteenth and early nineteenth century) raised funds a number of times and spent them for construction of a fence around the cemetery. ${ }^{67}$ Here is one such entry in the chronicle of the Holy Confraternity in 1751:

We have decided to allocate the necessary amount from the first available funds to erect the cemetery fence in its old place and fortify it; the ruler

\footnotetext{
${ }^{63}$ Klausner, Dzieje, p. 11.

${ }^{64}$ Ibid., p. 11; also see footnotes 44 and 78.

${ }^{65}$ Łopaciński, 'Horodnictwo Wileńskie', p. 81.

${ }^{66}$ AVAK, vol. XXIX (Vilnius, 1902), pp. 451-452, no. 225.

${ }^{67}$ Klausner, Dzieje, pp. 12-13.
} 
should be notified that an attempt to reduce fencing of the cemetery is an erroneous action. The purpose of the said amount may not change due to high importance of the cemetery issue. ${ }^{68}$

In 1758 the Jews approached Bishop Michał Jan Zienkowicz and received his permission to surround the cemetery with a wooden fence with stone posts. ${ }^{69}$ Having received the bishop's approval, the Jews undertook to implement it, but in order to ensure absolute safety from the Carmelites, they concluded an agreement with the latter concerning the disputed territory. The agreement stipulated that in return for an annual monetary payment as well as gifts in spices and meat the Carmelites would sell the Jewish cemetery a part of their land, where previously during different times of hardship (in the mid-seventeenth or late eighteenth century?) the Jewish dead were buried and thus the land was joined to their cemetery. ${ }^{70}$ At the same time the Jews invited two representatives of the Carmelites to confirm that the fence being built included the agreed territory and the land of the monastery was not occupied, which they did by their signatures. ${ }^{71}$ Regrettably as Klausner notes referring to the entry

${ }^{68}$ Ibid., p. 13.

${ }^{69}$ Ibid., pp.13-14 and XVIII-XIX (the document was published from SA 5136, fo. 40$)$.

${ }^{70}$ Ibid., pp. 14-15; LVIA, SA 4773, fo. 724-724v. Document dated 09 Nov. 1759: ...o kawat gruntu do rezidencyi naszey w Wilnie za willanowskiey Karmelitow Bossych będacego y nelezacego, a do mogit Zydowskich antiquitus zabranego bez przeszkody od WW Ichmew XX Karmelitow Bossych y do mogit przywlaszczonego antiquitus ieszcze tempore hostilitatis roznych inkursyi y powietrza in antiquitate gruntu mogitnego na ktorym wiele trupow zmartych pogrzebionych bez zadney przeszkody od WW Ichmęw XX Karmelitow... Ten tedy grunt Cum Consensu Communitatis rezidencyi za Willanowskiey $w$ Wilnie, nam za wiadomoscia y starszych prowincyi Ichm'XX Karmelitow ... Pozwolitem...Bractwa Zydow mogilnych... aby ten kawat gruntu nie byt bez zadnego pozytku sine usu et fructu szczupłosci mieysca na ktorym nie mozno // było ordynku wygodnego postawic y zeby te mieysce nie byto tak in ubilis globa et fertilis $w$ ten sposob pozwolitem przed starszym mogit Zydowskich nie czyniac alienacyi, za conditione ...

${ }^{71}$ Klausner, Dzieje, p. 14; LVIA, SA 4773, fo. 725-725v. Document dated 09 Nov. 1759: ...Ja X'dz Justinian od zmartwych wstania Panskiego Karmelita Bosych rezident Zawillanowski $w$ Wilnie czynie widomo tym moim skryptem testimonialnym Zydom starszym mogilnym danym na ti, iz pod czas obwarowania tych ze mogit stupami miedzy gruntow mogitkowych y gruntow klasztoru Ichmcw' XX Karmelitow Bossych $w$ Wilnie ZaWillanowskich bytem przytomny z O. Benonem ... ad mandata Illustrissimi loci ordinaryi investigando jezeliby przez dot obwarowanie niebyto jakiego pokrzywdzenia gruntow Ich mcw' XX Karmelitow..., albo przez to obwarowanie czyli oparkowanie stupami murowanemi nie było szkody tedy widzielismy, że te obwarowanie stupami czyli oparkanienie // na swoich zdawna granicach jak przed tym parkany zabudowanie byty y ze nam szkody ani krzywdy niebyto zadney... 
in the chronicle of the Holy Confraternity of 1762, irrespective of the agreement a few years later the Carmelites demanded a bigger payment and the confraternity decided to offer the friars 'a bribe of any requested amount'. Apparently it did help as the confraternity books later registered the following agreement:

The treasurers of the Holy Confraternity and a charity organisation (hevrah), after a lengthy and difficult discussion together, found a wise solution to the cemetery issue. They negotiated with the friars who wanted to cancel the old rights and take away a large part of our cemetery, and agreed for all times that the friars would be paid 5 reichsthalers each year in addition to presents of spices, otherwise a large fine would be imposed. ${ }^{72}$

Unfortunately the agreement 'for all times' lasted only a few years, because in 1770, incited by the friars, the residents of that dependent land destroyed the fence and stone posts of the cemetery dividing the disputed territory, damaged or smashed several tombstones. When the court official asked the Carmelites who did all that, they admitted their fault openly and noted that they had marked the territory of the cemetery they would order to be ploughed. ${ }^{73}$ The conclusion of that case is unknown but Klausner is probably right saying that 'the Jews were likely to regain the territory of their cemetery through bribes, additional payments and gifts'. ${ }^{74}$

The issue of the fence apparently remained problematic as the chronicle of the Holy Confraternity of the Vilnius Kahal stated that in 1783 for huge amounts of money the Jews had managed to obtain a new permit from Bishop Ignacy Massalski to fence the cemetery and have a free access to the cemetery. Furthermore, at the same

\footnotetext{
${ }^{72}$ Klausner, Dzieje, pp. 15-16.

${ }^{73}$ Ibid., p. 16; LVIA, SA 4785, fos. 330-330v. Document dated 11 Sept. 1770: ... Coram akty Grodu Wdztwa' Wilen'... Je jenerat JKm'... bytem uzyty y wezwany od niewiernych żydow... dla uczynienia wizyi rozraconey mogity przez w Bogu przewielebnych Ichmcw' XX Karmelitow Bosych za Wilio mieszkaiacych... na mogite przybyt tedy widziatem, iż XX karmelici Bosi 15 pratek(?) Parkanu między minowanemi stupami będacego rozrzucali stupy murowane dachowka kryte niektore popsali zruynowali ieden zas stup obwalili y z gruntu zdezolowali // Duszki 20 znaczeniem chowanych żydow z inskrypcyami żydowskiemi spędziwszy Juryzdyka cata popsuli zruynowawszy niektore do szczętu popsuli ktore to takowe gwattownosci przez Wielebnych XX Karmelitow Bosych za Wilio rezyduiacych poczynione $\dot{z}$ e widziałem pytaiqc że u samych XX Karmelitow... przez kogoby takowe krzywdy udzietane były alicui odpowiedzieli Ichm'XX Karm'że my juryzdyczanom swoim jako kazalismy rozrzucić tak y resztę mogiłek rozrzucim y poorać kazem gdzie y tyczki pozatykali na mieyscu gdzie mieysce pogrzebowe maia...

${ }^{74}$ Klausner, Dzieje, p. 16.
} 
time they bought a considerable land plot nearby. ${ }^{75}$ In this manner the Jews argued with their neighbours (particularly the Carmelites) regarding the cemetery boundaries and the fence throughout the eighteenth century.

It was no accident that permission to have free access to the cemetery was obtained as in 1765 Stanisław Piór (his surname gave rise to the street name and the neighbouring residential area Pioromont), the owner of the land plots near the Green Bridge on the right bank of the Neris (in the list of possessions of 1790 nos. 1075, 1076 ${ }^{76}$ ) being the starosta of Rumšiškès prohibited the Jews to carry their deceased by the old road along the Neris and indicated a new way (most likely the former Pioromont and nowadays Juozapavičiaus Street). ${ }^{77}$ According to Klausner until that time the Jews were buried by a special burial society for accompanying the dead and carrying the deceased, but since it failed to defend the old road, its functions were taken over by the special burial society tending the cemetery. ${ }^{78}$

In 1775 conducting an inventory census of Vilnius households or hearths, the Jewish cemetery with a residential building (apparently of a watchman) which was taxed 30 złoty were marked in the Jesuits' and later bishop's lands at Šnipiškès. ${ }^{79}$ In 1785 an inventory of that part of the town, the so- called Forestry Authority was conducted ${ }^{80}$ and it was noted that the Jewish cemetery was surrounded by a stone

${ }^{75}$ Ibid., p. 17.

${ }^{76}$ LVIA, SA 4068, fo. 41.

${ }^{77}$ Klausner, Dzieje, pp. XXIV-XXVIII (the document published from SA 5142, fo. 1335).

${ }^{78}$ Ibid., p. II.

${ }^{79}$ A. Baliulis, 'Vilniaus gyvenamujų namų $1775 \mathrm{~m}$. liustracijos duomenys, Lietuvos architektūros klausimai', VII, sąs. 2 (1982), p. 95; LVIA, SA 3337, fo. 16 (households (hearths - dümai) of the Forestry dependent lands are indicated below but there is no Castle jurisdiction. It seems to be either a mistake or at that time the lands in question could have been leased or mortgaged to the bishop).

${ }^{80}$ LVIA, SA 4025, fo. 1. Document dated 3 March 1785: Lustracya Derewnictwa Wilenskiego, prze zemnie Dworzanina przysięgtego nizey piszacego się, wedle dyspozycyi Nayiasnieyszey komissyi Skarbu uczyniona.

fo. 1a Opisanie granicy Derewnictwa Wilenskiego

Idac od rzeki Wilij ku mogiłom Żydowskim od mogit prosto az do drogi goscinca wielkiego do Malat idqcego po lewey stronie mieski grunt, daley idqc w prawo tym ze samym goscincem az do ruczaju Wilczełapy zwanego granica bez kwestyi po lewey stronie grunta mieskie: tym ze ruczaiem $w$ prawo idac az do rzeki Wilij po lewey stronie gruntu Ichmcw'Xięży Dominikanow Wilenskich. Ta sama rzeka połowa plynacey wody az ku mogitom Żydowskim graniczy. 
wall and as the Jews said a part of the cemetery was on the land of the castle warden and a part lay on the land of the Carmelites. They also acknowledged that they had occupied a few land plots of the Forestry but undertook to pay taxes for them. Furthermore, like the other local residents the Jews failed to provide the ownership documents. After four years a dispute arose between the elders of the Vilnius Kahal and Urbanowicz, appointed to manage the Forestry lands, because according to the last inventory only 24 złoty had been paid for a land plot of the cemetery and still a debt had accrued whereas a few dozen złoty were paid for each burial. ${ }^{81}$ Apparently the conflict was solved only in the last years of the state (in 1795),

Z Ichmcyi tamecznych mieszkancow wyraza się iz miasto zaięła wielki kawat gruntu od mogił Żydowskich ku Zielonemu mostowi. [...]

Mogity Żydowskie cate omurowane na Derewnickim gruncie wymawiaia sie Żydzi iz częsci tych mogił jedna do Horodnictwa Wilenskiego, druga do JXX Karmelitow Bosych nalezq. Jednak dobrowolnie zeznaiq się: iz zaieli kilka placow Derewnickich y znich obowiazali corocznie płacic po złotych Polskich 24. Dico 24.

fo. lav Domagatem się tak u miasta, u Ichm' Xięzy Bosakow y u WJ Pana Abramowicza, jako tez y zydow, o ukazanie na te dzierzy dokumentow zadnych niezłozono. [...]

Rybacy za naięcie brzegow rzeki Wilij placa na rok zll' 8. Grunta Derwnictwa Wilenskiego obszernosci niemaley, lecz potrzeba wymiaru onego z opisaniem pewney granicy.

fo. 2 Inwentarz mieszkancow Derwnictwa Wilenskiego

Dymy Place Placa corocznie dwoma Ratami Kwarta Podymne Czynsz

\section{Andrzey Kozlowskiz pustosza}

$[\ldots]$

$\begin{array}{lll}\text { Zll gr } & \text { zll gr } & \text { zll } g r \\ 32- & 4- & 6- \\ 24 & 4- & \\ 24 & \end{array}$

Z innych placow ogulnie placo

Zydzi z zaiętych kilka placow

[...] (The author is grateful to Domininkas Burba for suggestions concerning this issue).

${ }^{81}$ LVIA, SA 4804, fos. 800-801. Document dated 10 Sept 1789: Zeznanie mandatu w sprawie WIPa Urbanowicza z zydami. ...Przed aktami Grodz' W Wo...w te stowa pisanq Stanisław August krol... co do rzeczoney kwaty ad mentem aktu licytacyi zas tranzaktow wszelkich niewolnie in praejuditiam skarbu Rzpttey' WXL na awulsa dzierzawy Derewnickiey gdy by się okazaly od kogo kolwiek bez prawnie wydawane y formowane skassowania odestania do urodz' dell'ra na ugodzenie sie Tarragij jako uprzywiliowanego aktora y possesora placow Derewnickich mogiłami czyli kopiszczami zaiętych do złozenia subnexu juramenti przez lat cztery branych przez $N^{\prime} z y d o w$ pięniędzy od osob chowaiqcych się za mieysca niemal za kazdq osobę po kilkadziesiat czer' ztl'ch a urodz'u aktorowi placow zwrocenia za narazenie dell'ra niewolno y uporne do processu penami ukarania expensow prawnych do zlt'ch poll'ch czterysta causa obtt'ch $N$ 'zydow spędowanych sqdzenia y tego wszytkiego uznania co przez kontrawersya obszerniey dowiedzionym będzie z wolna poprawq tey załoby piron ... 
when according to Klausner, who refers to the chronicle of the Holy Confraternity, the Jews undertook to increase the annual fee for the land plots and pay 40 złoty. ${ }^{82}$

In the list of Vilnius hearths of 1790 the Jewish cemetery with a residential house and a fence are indicated as possession no. 1116. ${ }^{83}$ Apparently at that time when the possession (No. 1116) was documented all the above mentioned land plots the Jewish cemetery consisted of were joined into one irregular rectangular which appears in a number of plans from the end of the eighteenth century and later periods. We have not succeeded in finding possession No. 1116 in descriptions of Vilnius possessions made in early nineteenth century (also called Chronicle Books) where only a few neighbouring possessions are described noting their contact with the Jewish cemetery. ${ }^{84}$ The same year of 1790 the Treasury Commission allowed the parish priest of St Teresa's Church and alms-house to collect the following fee for the repairs of the Green Bridge in addition to other charges: 'For carrying an old dead Jew together with accompanying mourners -1 złoty and 8 groats; for carrying dead children -1 złoty and 13 groats; for carrying a wooden or stone [Jewish] tombstone -1 złoty and 13 groats'. ${ }^{85}$

When in 1795 the Polish-Lithuanian Commonwealth collapsed, the territory of the Grand Duchy of Lithuania with its capital Vilnius became a part of the Russian Empire. The status of Jews in that country changed since from freemen they became subjects of the tsar and the imperial authorities resorted to brutal measures to integrate them. Vilnius old Jewish cemetery at Šnipiškès associated with the history of the GDL soon seized to exist as in 1831 it was closed and to some extent ruined.

${ }^{82}$ Klausner, Dzieje, p. 10.

${ }^{83}$ LVIA, SA 4068, fo. 43, possession no. 1116 Mieszkaniq z ogrodem mogitki żydowskie.

No. 1117 Chatupa ogrodowa XX Bernardynow. (In 1812-1813 a brickyard of Bernardines stood there, see V. Drèma, Vilniaus namai archyvu fonduose, kn. VII (Vilnius, 2003), fo. 91, there is no data concerning no. 1116 and no. 1118 and in case of no. 1119 it is indicated that in 1828-1830 it was at either Pylimo or Pilies Street), no. 1118 Klasztor XX Karmelitow przy k. S. Tereszy. No. 1119 Dom pokontny Kudhanowskiego. Derewnictwo.

${ }^{84}$ LVIA, f. 458 , ap. 1, b. 531-539 (B. 531, fo. 30v - posession no. 1114, fo. $36 \mathrm{v}$ - no. 1103 ; B. 532 , fo. $1 \mathrm{v}-$ no. 1101 , fo. $4 \mathrm{v}-$ no. 1115$)$.

${ }^{85}$ Klausner, Dzieje, p. 24; LVIA, SA 2781, fo. 8. 
To conclude the history of the cemetery in question during the period of the GDL, we may note that the cemetery was established on royal land in the Castle jurisdiction exempt from taxes possibly in the late fifteenth century and the first reliable historical data are found from late sixteenth century. A comparison of historical, cartographic and archaeological data permits us to draw a valid assumption that the oldest burials from the second half of the sixteenth century were located in the south-western and central section of the cemetery based on the layout of 1808 (in the area between the Sports Hall built in the Soviet period and the former swimming pool). The cemetery developed gradually by acquiring separate state land plots located on the Castle and Forestry lands which were leased by different owners and by taking over the taxes they used to pay. The general situation of the cemetery at that period was marked in the Vilnius plan of the Fürstenhof collection drafted in approximately 1730 . The Jewish cemetery was combined into a solid cemetery formation out of separate plots around 1790 in listing the urban possessions (land plots). Such situation was reflected in the layout of 1808 (possession no. 1116).

\section{Author Details}

Dr Elmantas Meilus is a member the Department of Urban Research of the Lithuanian Institute of History. His sphere of scholarly interests is history of Lithuanian cities and towns in the 17th and 18th centuries.

Address: Department of Urban Research, Lithuanian Institute of History, Kražių 5, LT-01108 Vilnius

Email: meilus@istorija.1t 


\title{
SENUUJU VILNIAUS ŽYDU KAPINIŲ ŠNIPIŠKĖSE ISTORIJA LIETUVOS DIDŽIOSIOS KUNIGAIKŠTYSTĖS LAIKAIS
}

\author{
Santrauka
}

\section{ELMANTAS MEILUS}

Pastaruoju metu kilęs tarptautinis triukšmas dẻl vẻl naikinamų senujų žydų kapinių buvusiame Vilniaus Šnipiškių priemiestyje (dabar esančių pačiame miesto centre), verčia iš naujo peržvelgti jų atsiradimo ir raidos istoriją Lietuvos Didžiosios Kunigaikštystès (toliau LDK) laikais. Apibendrinant šiu kapinių istoriją LDK laikais galima būtu padaryti išvadas, kad kapinès buvo ikurtos valstybineje Pilies jurizdikos žemėje galbūt XV a. pabaigoje, o pirmi patikimi istoriniai duomenys aptinkami iš XVI a. pabaigos, atleidžiant nuo mokesčių. Palyginus istorinius, kartografinius ir archeologinius duomenis, galima daryti tvirtą prielaida, kad seniausi palaidojimai nuo XVI a. II pusès buvo pietvakarinejje ir centrinejje kapinių dalyse pagal $1808 \mathrm{~m}$. planą (tarp sovietmečiu pastatytų Sporto rūmų ir buvusio baseino). Kapinès formavosi palaipsniui, supirkinėjant atskirus sklypus buvusius valstybinèse Pilies (Horodnictwo) ir Eiguvos (Derewnictwo) jurizdikų žemėse, bet nuomojamų skirtingų savininku, ir perimant jų mokètus mokesčius. Bendra to laiko kapinių situacija yra pažymèta apie $1730 \mathrm{~m}$. sudarytame Furstenhofo rinkinio plane. Iš atskiru sklypu i vientisą kapinių masyvą žydų kapinès buvo suformuotos apie 1790 m., sudarant miesto posesijų (sklypu) sąrašą. Ši situacija atsispindi 1808 m. plane (posesijos nr. 1116). 